\title{
Pollution Problem in River Kabul: Accumulation Estimates of Heavy Metals in Native Fish Species
}

\author{
Habib Ahmad, ${ }^{1}$ Ali Muhammad Yousafzai, ${ }^{2}$ Muhammad Siraj, ${ }^{3}$ \\ Rashid Ahmad, ${ }^{4}$ Israr Ahmad, ${ }^{1}$ Muhammad Shahid Nadeem, ${ }^{1}$ Waqar Ahmad, ${ }^{1}$ \\ Nazia Akbar, ${ }^{1}$ and Khushi Muhammad ${ }^{1}$ \\ ${ }^{1}$ Department of Genetics, Hazara University, Mansehra 21300, Pakistan \\ ${ }^{2}$ Department of Zoology, Islamia College, Peshawar 25000, Pakistan \\ ${ }^{3}$ Department of Zoology, Hazara University, Mansehra 21300, Pakistan \\ ${ }^{4}$ Department of Chemistry, Malakand University, Chakdara 18800, Pakistan
}

Correspondence should be addressed to Habib Ahmad; drhahmad@gmail.com

Received 27 November 2014; Revised 19 May 2015; Accepted 26 May 2015

Academic Editor: Sunil Kumar

Copyright (C) 2015 Habib Ahmad et al. This is an open access article distributed under the Creative Commons Attribution License, which permits unrestricted use, distribution, and reproduction in any medium, provided the original work is properly cited.

\begin{abstract}
The contamination of aquatic systems with heavy metals is affecting the fish population and hence results in a decline of productivity rate. River Kabul is a transcountry river originating at Paghman province in Afghanistan and inters in Khyber Pakhtunkhwa province of Pakistan and it is the major source of irrigation and more than 54 fish species have been reported in the river. Present study aimed at the estimation of heavy metals load in the fish living in River Kabul. Heavy metals including chromium, nickel, copper, zinc, cadmium, and lead were determined through atomic absorption spectrophotometer after tissue digestion by adopting standard procedures. Concentrations of these metals were recorded in muscles and liver of five native fish species, namely, Wallago attu, Aorichthys seenghala, Cyprinus carpio, Labeo dyocheilus, and Ompok bimaculatus. The concentrations of chromium, nickel, copper, zinc, and lead were higher in both of the tissues, whereas the concentration of cadmium was comparatively low. However, the concentration of metals was exceeding the RDA (Recommended Dietary Allowance of USA) limits. Hence, continuous fish consumption may create health problems for the consumers. The results of the present study are alarming and suggest implementing environmental laws and initiation of a biomonitoring program of the river.
\end{abstract}

\section{Introduction}

River Kabul is the largest river of Hindu Kush Mountains. It serves as the main drainage basin of most of the valleys of Hindu Kush Mountains. The River is fed by two main tributaries, that is, River Chitral and River Swat. It originates from the base of the Unai Pass [1] in the Paghman Mountains in Afghanistan, whereas the rivers Chitral and Swat originate from Mastuj Mountains and Hindu Raj Mountains of Chitral and Swat mountains in Pakistan, respectively. The River provides habitat for the variety of life forms, including 54 fish species, mainly belonging to the Carp and Mystus families; out of which some of the species, for example, Botia rostrata, are endemic to River Kabul Pakistan (reviewed in [2,3]).
The risk issues, assessment, and maintaining the quality of environment are the main focus of the researchers. The estimation and monitoring of environmental pollution are becoming increasingly important to develop different monitoring methods and strategies (reviewed in [4]). Heavy metal pollution is a major environmental concern issue, which is mainly contributed by sewage and industrial waste and agricultural run-off. Natural phenomena such as earthquake, landslides, tornadoes, cyclones, and weathering of rocks also contribute towards heavy metal pollution. Heavy metals such as lead, cadmium, copper, and nickel present in the aquatic environment have accumulated in fish body which have led to toxic events in the past [5]. More than 72 small- and large-scale industries are discharging their untreated effluents 
to River Kabul [6], which certainly is affecting the quality of water and thereby the fish health and production. Less information is available about heavy metals load in edible fishes of River Kabul.

Our study aimed to assess and determine the chromium, nickel, copper, zinc, cadmium, and lead concentrations in the muscles and liver of five common edible fish species like Mulee (Wallago attu), Singhara (Aorichthys seenghala), common carp (Cyprinus carpio), torki (Labeo dyocheilus), and Shermai (Ompok bimaculatus).

\section{Materials and Methods}

2.1. Sampling Procedure. Five fish species, namely, Wallago attu, Ompok bimaculatus, Labeo dyocheilus, Cyprinus carpio, and Aorichthys seenghala, of different sizes and weights were caught from River Kabul during late night with the help of local fisher men through Gill Net of $40 \times 6 \mathrm{ft}$. with a cork line at the top rope and metal line with the ground rope made locally of nylon wire. Sampling was carried out downstream Nowshera city where river becomes narrow and the pollutants concentration rises after city effluent discharges. Fish samples were temporarily stored in iceboxes and identified by the procedures described by Butt and Mirza [7]. Fishes were washed with distilled water and dissected for sampling of various tissues. Weighed portions $(2.0 \mathrm{~g})$ of the tissue (muscle and liver) were excised and kept in labeled sterilized polythene sampling bags in the deep freezer at $-20^{\circ} \mathrm{C}$.

2.2. Estimation of Heavy Metals. For estimation of heavy metals, the tissue samples were thawed, rinsed in distilled water, and blotted and known weights $(0.2 \mathrm{~g})$ were shifted to $100 \mathrm{~mL}$ sterilized volumetric flasks. The samples were digested according to the modified protocol of van den Heever and Frey [8] and Yousafzai and Shakoori [9]. The modification was that, instead of putting $10 \mathrm{~mL}$ nitric acid (55\%) and $5.0 \mathrm{~mL}$ perchloric acid $(70 \%)$ at the time of digestion, $5.0 \mathrm{~mL}$ nitric acid (55\%) and $1.0 \mathrm{~mL}$ perchloric acid (70\%) were added to each sample and the flasks were kept lid tight overnight. After $24 \mathrm{~h}, 5.0 \mathrm{~mL}$ nitric acid (55\%) and $4.0 \mathrm{~mL}$ perchloric acid (70\%) were added to each flask. The flasks were then placed on a hot plate and allowed to digest at 200 to $250^{\circ} \mathrm{C}$ until a transparent solution was obtained. After digestion, samples were cooled and diluted to $10.0 \mathrm{~mL}$ with distilled water. Determination of heavy metals, that is, nickel, copper, zinc, cadmium, and lead, was done by atomic absorption spectrophotometer (Spectra-AA-700). Three different fishes of the same species were analyzed and the results were the average of triplicate independent measurements. Mean and standard error of mean values of estimates were recorded and compared. The standard conditions were set on atomic absorption spectrophotometer during analysis (Table 1).

A range of analytical standards for each metal was prepared from E. Merck stock solution. Standard curves were prepared and the ODs (optical densities) obtained were calibrated against the standard curves to know the concentration of heavy metals.
TABLE 1: The standards used to analyze the variable using atomic absorption spectrophotometer (Spectra-AA-700).

\begin{tabular}{lcccc}
\hline Element & $\begin{array}{c}\text { Wavelength } \\
(\mathrm{nm})\end{array}$ & $\begin{array}{c}\text { Flame gases (A-AC } \\
\text { air acetylene) }\end{array}$ & $\begin{array}{c}\text { Lamp current } \\
\text { (m-ampere) }\end{array}$ & $\begin{array}{c}\text { Band } \\
\text { pass }\end{array}$ \\
\hline $\mathrm{Cr}$ & 357.9 & A-AC & 10 & 0.5 \\
$\mathrm{Cu}$ & 324.7 & A-AC & 5 & 0.5 \\
$\mathrm{~Pb}$ & 283.3 & A-AC & 10 & 0.5 \\
$\mathrm{Ni}$ & 232.0 & A-AC & 15 & 0.2 \\
$\mathrm{Zn}$ & 213.9 & A-AC & 8 & 0.5 \\
\hline
\end{tabular}

\section{Results and Discussions}

Results show that accumulation of heavy metals adversely affects liver and muscles, which directly affect the growth and development of fishes. Muscle is suggested to be the major tissue of interest for monitoring of environmental contamination with metals [9]. Liver in fish plays a protective role against metal exposure, by acting as a storage site and being a vital organ in the regulation of metals. Large amount of metallothioneins (MTs) protein induction occurs in the liver tissue of fish thus acting as a major sequestering organ. Therefore, the liver is considered as one of the major metal bioaccumulation organs [10]. Histopathological lesions of liver proved to be the most sensitive and reliable indicators of metal exposure [11].

Results obtained for accumulation of heavy metals in muscle and liver tissues of the fish species are summarized in Tables 2 and 3, respectively. Our findings revealed that the accumulation profile was highly variable among different species and different samples of the same species. Variations in accumulation of metals were even recorded in different tissues of the 96 same fish. These findings are in conformity of similar studies carried out elsewhere $[12,13]$. The presence of high metal concentrations in fishes can simply be correlated to the presence of higher metal concentration in water and sediments of River Kabul as reported by Yousafzai and Shakoori [9] and Trevor and Stephan [6]. According to Trevor and Stephan [6], the concentration of chromium in ambient water downstream Nowshera ranged $0.068-0.64 \mathrm{mg} / \mathrm{L}$, $\mathrm{Zn}$ ranged $0.35-0.52 \mathrm{mg} / \mathrm{L}$, Co ranged $0.38-0.48 \mathrm{mg} / \mathrm{L}, \mathrm{Ni}$ ranged $0.04-0.074 \mathrm{mg} / \mathrm{L}$, and $\mathrm{Pb}$ ranged $0.006-0.141 \mathrm{mg} / \mathrm{L}$. The comparison of our findings with that of Yousafzai and Shakoori [9] showed the levels of heavy metal accumulation enhanced with the passage of time. This reflects that in the past few years a further increase in the level of heavy metals has occurred in the river water, which is suggestive of the implementation of proper environmental laws and a biomonitoring program for the river.

Natural water may receive chromium from the industrial effluents [14]; once absorbed, it passes into the blood and is distributed to various organs, particularly the liver. The liver serves as a primary storage and detoxification site for chromium. In the liver, chromium is stored, linked to proteins smaller peptides, and induces changes in blood and tissue metabolism with acute and chronic poisoning leading to hyperglycemia and glycogenolysis in the brain and liver. 
TABLE 2: Metal concentration ( $\mu \mathrm{g} / \mathrm{g}$ wet weight) in liver and muscles of selected edible fish species of River Kabul.

\begin{tabular}{|c|c|c|c|c|}
\hline Serial number & Fish species & Metal & $\begin{array}{c}\text { Liver }(n=3) \\
\text { mean } \pm \text { S.E }\end{array}$ & $\begin{array}{c}\text { Muscle }(n=3) \\
\text { mean } \pm \text { S.E }\end{array}$ \\
\hline \multirow{6}{*}{1} & \multirow{6}{*}{ Wallago attu } & Chromium & $509.7 \pm 95.8$ & $533.3 \pm 206.1$ \\
\hline & & Nickel & $108.0 \pm 19.9$ & $106.7 \pm 6.8$ \\
\hline & & Copper & $513.0 \pm 159.7$ & $46.3 \pm 29.0$ \\
\hline & & Zinc & $136.0 \pm 9.6$ & $649.0 \pm 107.0$ \\
\hline & & Cadmium & $64.3 \pm 7.6$ & $68.0 \pm 15.0$ \\
\hline & & Lead & $623.3 \pm 276.5$ & $599.3 \pm 188.3$ \\
\hline \multirow{6}{*}{2} & \multirow{6}{*}{ Aorichthys seenghala } & Chromium & $2279.7 \pm 1614.9$ & $565.3 \pm 148.7$ \\
\hline & & Nickel & $117.7 \pm 13.3$ & $94.7 \pm 33.3$ \\
\hline & & Copper & $619.0 \pm 161.9$ & $132.7 \pm 13.4$ \\
\hline & & Zinc & $220.7 \pm 8.2$ & $1167.7 \pm 230.8$ \\
\hline & & Cadmium & $64.7 \pm 14.0$ & $60.7 \pm 17.2$ \\
\hline & & Lead & $240.0 \pm 104.2$ & $350.7 \pm 37.2$ \\
\hline \multirow{6}{*}{3} & \multirow{6}{*}{ Cyprinus carpio } & Chromium & $3319.0 \pm 376.8$ & $489.0 \pm 49.7$ \\
\hline & & Nickel & $80.0 \pm 16.1$ & $74.7 \pm 17.3$ \\
\hline & & Copper & $493.7 \pm 56.5$ & $303.0 \pm 255.8$ \\
\hline & & Zinc & $390.0 \pm 13.5$ & $826.3 \pm 166.6$ \\
\hline & & Cadmium & $58.0 \pm 2.9$ & $53.3 \pm 2.9$ \\
\hline & & Lead & $261.3 \pm 72.7$ & $226.3 \pm 222.2$ \\
\hline \multirow{6}{*}{4} & \multirow{6}{*}{ Labeo dyocheilus } & Chromium & $1175.7 \pm 649.0$ & $647.3 \pm 105.1$ \\
\hline & & Nickel & $111.7 \pm 21.4$ & $117.7 \pm 33.5$ \\
\hline & & Copper & $643.7 \pm 64.9$ & $191.7 \pm 30.6$ \\
\hline & & Zinc & $1644.0 \pm 691.6$ & $883.0 \pm 185.3$ \\
\hline & & Cadmium & $72.3 \pm 10.3$ & $66.7 \pm 8.5$ \\
\hline & & Lead & $377.0 \pm 300.2$ & $528.7 \pm 236.4$ \\
\hline \multirow{6}{*}{5} & \multirow{6}{*}{ Ompok bimaculatus } & Chromium & $860.0 \pm 160.8$ & $703.0 \pm 125.3$ \\
\hline & & Nickel & $100.3 \pm 66.8$ & $135.0 \pm 52.6$ \\
\hline & & Copper & $670.7 \pm 182.0$ & $241.3 \pm 40.1$ \\
\hline & & Zinc & $164.0 \pm 101.3$ & $902.0 \pm 112.8$ \\
\hline & & Cadmium & $138.3 \pm 93.7$ & $71.7 \pm 12.1$ \\
\hline & & Lead & $1390.0 \pm 1530.2$ & $407.0 \pm 126.6$ \\
\hline
\end{tabular}

Mean values of the accumulated $\mathrm{Cr}$ in muscles of $W$. attu, A. seenghala, C. carpio, L. dyocheilus, and O. bimaculatus were $533.3 \pm 206.1,565.3 \pm 148.7,489.0 \pm 49.7,647.3 \pm$ 105.1 , and $703.0 \pm 125.3$ while its concentration in liver was $513.0 \pm 159.7,619.0 \pm 161.9,493.7 \pm 56.5,643.7 \pm$ 64.9 , and $670.7 \pm 182.0 \mu \mathrm{g} / \mathrm{g}$ wet weight, respectively (Tables 2 and 3). The $\mathrm{Cr}$ concentration in tissues of fish species was in the order of O. bimaculatus $>$ L. dyocheilus $>A$. seenghala $>W$. attu $>C$. carpio. This shows that the metal accumulation is highest in $O$. bimaculatus and lowest in $C$. carpio. Bhattacharya et al. [15] have reported highest level of $\mathrm{Cr}$ in muscle tissue of commercially edible fishes from upper stretch of the Ganga River at West Bengal, India. Similarly, Yilmaz [16] has reported 1.46 and $1.28 \mu \mathrm{g} / \mathrm{g}$ of Cr in the muscle of Mugil cephalus and Trachurus mediterraneus respectively in some fishes caught from Turkey. In another study Olaifa et al. [17] reported $0.07 \mathrm{ppm}$ of $\mathrm{Cr}$ in the muscle of Clarias gariepinus got from Eleiyele Lake and Zartech fish farm in
Ibandan, Nigeria. Türkmen et al. [18] have also recorded $0.07-6.46 \mathrm{mg} / \mathrm{g} \mathrm{k}^{-1}$ of $\mathrm{Cr}$ in three commercially valuable fish species, Saurida undosquamis, Spamrus aurata and Mullus baratus from Iskenderun Bay, North East Mediterranean Sea, Turkey. Demirezen and Uruç [19] have reported 8.44 and 9.51 $(\mu \mathrm{g} / \mathrm{g})$ of $\mathrm{Cr}$ in certain fishes from Kayseri, Turkey. Yousafzai and Shakoori [9] recorded high levels of Cr $5.90 \pm 0.04$ and $3.2 \pm 0.05 \mu \mathrm{g} / \mathrm{g}$ wet weight, in muscle and liver of Tor putitora from River Kabul. Our findings suggest that River Kabul has more concentration of $\mathrm{Cr}$ as compared to other water bodies, mentioned above, and the concentration of $\mathrm{Cr}$ is comparatively high. The accumulation of heavy metals in the muscle of coastal fishes has been studied and predominant bioaccumulation of Fe, $\mathrm{Zn}$, and $\mathrm{Cu}$ was recorded by Kumar et al. [20].

Nickel is capable of producing severe physiological changes during the past few years, causing failure of the respiratory mechanism resulting in enhanced rates of mortality of the fish species [21]. Chronic low level of nickel 
TABLE 3: Heavy metals concentrations $\mu \mathrm{g} / \mathrm{g}$ in liver samples of edible fish species of River Kabul.

\begin{tabular}{|c|c|c|c|c|c|c|}
\hline \multirow{2}{*}{ Fish } & \multirow{2}{*}{ Metals } & \multicolumn{3}{|c|}{ Sample number } & \multirow{2}{*}{ Mean } & \multirow{2}{*}{ Standard deviation } \\
\hline & & 1 & 2 & 3 & & \\
\hline \multirow{6}{*}{ Wallago attu } & Zinc & 385 & 618 & 526 & 509.7 & $509.7 \pm 95.8$ \\
\hline & Nickel & 80 & 125 & 119 & 108.0 & $108.0 \pm 19.9$ \\
\hline & Chromium & 731 & 559 & 249 & 513.0 & $513.0 \pm 159.7$ \\
\hline & Copper & 133 & 126 & 149 & 136.0 & $136.0 \pm 9.6$ \\
\hline & Cadmium & 72 & 67 & 54 & 64.3 & $64.3 \pm 7.6$ \\
\hline & Lead & 723 & 901 & 246 & 623.3 & $623.3 \pm 276.5$ \\
\hline \multirow{6}{*}{ Aorichthys seenghala } & Zinc & 4553 & 1333 & 953 & 2279.7 & $2279.7 \pm 1614.9$ \\
\hline & Nickel & 112 & 136 & 105 & 117.7 & $117.7 \pm 13.3$ \\
\hline & Chromium & 598 & 827 & 432 & 619.0 & $619.0 \pm 161.9$ \\
\hline & Copper & 231 & 211 & 220 & 220.7 & $220.7 \pm 8.2$ \\
\hline & Cadmium & 59 & 84 & 51 & 64.7 & $64.7 \pm 14.0$ \\
\hline & Lead & 120 & 374 & 226 & 240.0 & $240.0 \pm 104.2$ \\
\hline \multirow{6}{*}{ Cyprinus carpio } & Zinc & 3487 & 2797 & 3673 & 3319.0 & $3319.0 \pm 376.8$ \\
\hline & Nickel & 102 & 64 & 74 & 80.0 & $80.0 \pm 16.1$ \\
\hline & Chromium & 462 & 573 & 446 & 493.7 & $493.7 \pm 56.5$ \\
\hline & Copper & 371 & 398 & 401 & 390.0 & $390.0 \pm 13.5$ \\
\hline & Cadmium & 57 & 62 & 55 & 58.0 & $58.0 \pm 2.9$ \\
\hline & Lead & 174 & 352 & 258 & 261.3 & $261.3 \pm 72.7$ \\
\hline \multirow{6}{*}{ Labeo dyocheilus } & Zinc & 842 & 602 & 2083 & 1175.7 & $1175.7 \pm 649.0$ \\
\hline & Nickel & 121 & 132 & 82 & 111.7 & $111.7 \pm 21.4$ \\
\hline & Chromium & 658 & 715 & 558 & 643.7 & $643.7 \pm 64.9$ \\
\hline & Copper & 1143 & 1167 & 2622 & 1644.0 & $1644.0 \pm 691.6$ \\
\hline & Cadmium & 74 & 84 & 59 & 72.3 & $72.3 \pm 10.3$ \\
\hline & Lead & 797 & 221 & 113 & 377.0 & $377.0 \pm 300.2$ \\
\hline \multirow{6}{*}{ Ompok bimaculatus } & Zinc & 710 & 1083 & 787 & 860.0 & $860.0 \pm 160.8$ \\
\hline & Nickel & 43 & 194 & 64 & 100.3 & $100.3 \pm 66.8$ \\
\hline & Chromium & 545 & 928 & 539 & 670.7 & $670.7 \pm 182.0$ \\
\hline & Copper & 42 & 290 & 160 & 164.0 & $164.0 \pm 101.3$ \\
\hline & Cadmium & 269 & 92 & 54 & 138.3 & $138.3 \pm 93.7$ \\
\hline & Lead & 3545 & 141 & 484 & 1390.0 & $1390.0 \pm 1530.2$ \\
\hline
\end{tabular}

exposure can cause serious lung damage, birth defects, kidney diseases, lung cancer, and so forth [22]. Mean values of Ni in muscles of $W$. attu, A. seenghala, C. carpio, L. dyocheilus, and $O$. bimaculatus were $106.7 \pm 6.8,94.7 \pm 33.3,74.7 \pm 17.3$, $117.7 \pm 33.5$, and $135.0 \pm 52.6$ (Table 2). In livers, however, its concentration was $108.0 \pm 19.9,117.7 \pm 13.3,80.0 \pm 16.1$, $111.7 \pm 21.4$, and $100.3 \pm 66.8 \mu \mathrm{g} / \mathrm{g}$ wet weight, respectively (Table 2). Ni concentration in muscles of different fish species was in the order of O. bimaculatus $>$ L. dyocheilus $>$ W. attu $>$ A. seenghala $>$ C. carpio. This shows that the bioaccumulation of $\mathrm{Ni}$ was highest in the muscle of $\mathrm{O}$. bimaculatus and lowest in C. carpio. In the liver, it was in the order of $>$ seenghala $>$ dyocheilus $>$ attu $>$ bimaculatus $>$ carpio. This shows that the $\mathrm{Ni}$ absorption is lowest in the liver of carpio and highest in seenghala. The wide difference in bioaccumulation might be due to herbivorous nature of carpio. Being herbivorous, it is less exposed to metal bioaccumulation. Yilmaz [16] has reported 1.22 and $0.94 \mu \mathrm{g} / \mathrm{g}$ of $\mathrm{Ni}$ in the wet weight muscles of Mugil cephalus and mediterraneus, respectively, caught in Iskenderun Bay, Turkey. Yousafzai and Shakoori [9] have also
TABLE 4: US Recommended Daily Dietary Allowance (RDA) supplied by a $100 \mathrm{~g}$ of fish muscle.

\begin{tabular}{lcc}
\hline Metals & Concentration $(\mathrm{mg})$ & Microgram $(\mu \mathrm{g})$ \\
\hline Zinc & 2.6 & 2600 \\
Nickel & 0.01 & 10 \\
Chromium & $0.05-0.20$ & $50-200$ \\
Copper & $2.0-3.0$ & $2000-3000$ \\
Cadmium & 0.014 & 14 \\
Lead & 0.3 & 300 \\
\hline
\end{tabular}

reported high level of $\mathrm{Ni} 87 \pm 6.04,113 \pm 11.74 \mu \mathrm{g} / \mathrm{g}$ wet weight, in muscle and liver of the fish, putitora, caught from the same water body. Bioaccumulation of $\mathrm{Ni}$ in all the fishes surpasses the RDA limits of $10 \mu \mathrm{g} / 100 \mathrm{~g}$ (Table 4).

Copper is an essential element, but it is toxic in excess. From a dietary perspective, the primary toxic action is predominantly the production of free radicals in tissues where 
copper accumulates. In addition, dietary copper toxicity can occur at several other loci in the gut and includes inhibition of digestive enzymes and reduced gut motility [23].

Variation of copper accumulation in the muscle and liver of fish species is presented in Tables 2 and 3. In muscles, the bioaccumulation varied in the order of C. carpio $>O$. bimaculatus $>$ L. dyocheilus $>$ A. seenghala $>W$. attu, which shows that its accumulation was highest in the muscle of $C$. carpio and lowest in W. attu. Bhattacharya et al. [15] have reported 1.45 and $1.29 \mu \mathrm{g} / \mathrm{g}$ wet weights of $\mathrm{Cu}$ in the muscles of the fish species, cephalus and mediterraneus, respectively. Yap et al. [24] have also recorded $1.98 \mu \mathrm{g} / \mathrm{g}$ wet weight of $\mathrm{Cu}$ in the edible flesh (muscles) Oreochromis mossambicus. Different studies [9, 25-27] concluded that the concentration of $\mathrm{Cu}$ varies significantly in different species of fish species. $\mathrm{Cu}$ in liver of $W$. attu was generally with a mean value of $136.0 \pm 9.6$, in A. seenghala was $220.7 \pm 8.2$, in A. carpio was $390.0 \pm 13.5$, L. dyocheilus was $1644.0 \pm 691.6$, and Ompok bimaculatus was with mean value of $164.0 \pm 101.3 \mu \mathrm{g} / \mathrm{g}$ of the wet weight. $\mathrm{Cu}$ concentration in liver was however in the order of $d y o c h e i l u s$ $>$ carpio $>$ seenghala $>$ bimaculatus $>$ attu. This shows that the metal bioaccumulation was highest in the liver of dyocheilus and lowest in bimaculatus. Similar results were observed by Subathra and Karuppasamy [26] who recorded 82.12 and $70.65 \mu \mathrm{g} / \mathrm{g}$ of $\mathrm{Cu}$ in the liver of different sizes fingerlings and adult of healthy Mystus vittatus. However, Ruelas-Inzunza and Páez-Osuna [27] reported $48.6 \mu \mathrm{g} / \mathrm{g}$ of $\mathrm{Cu}$ in liver of sperm whale (Physeter catodon). In another study, Clearwater et al. [28] have reported $667 \pm 81\left(\mu \mathrm{g} \mathrm{kg}^{-1}\right)$ of $\mathrm{Cu}$ in liver of rainbow trout. Although the situation of Copper in the fish species of River Kabul is alarming, it is not the worst like other heavy metals.

Zinc generally enters the fish bodies via gills, general body surface, and alimentary canal and its excretion takes place mainly via the gastrointestinal tract. Mean values for the concentration of $\mathrm{Zn}$ in the muscles of $W$. attu, A. seenghala, C. carpio, L. dyocheilus, and O. bimaculatus were $649.0 \pm$ $107.0,1167.7 \pm 230.8,826.3 \pm 166.6,883.0 \pm 185.3$, and $902.0 \pm 112.8 \mu \mathrm{g} / \mathrm{g}$, respectively, in the wet weight of the muscles (Table 1). The concentration of $\mathrm{Zn}$ was in the order of $A$. seenghala $>O$. bimaculatus $>$ L. dyocheilus $>C$. carpio $>W$. attu. This shows that the metal bioaccumulation was highest in the muscle of $A$. seenghala and lowest in $W$. attu. Yilmaz [16] recorded 38.23 and $19.55 \mu \mathrm{g} / \mathrm{g}$ wet weight of $\mathrm{Zn}$ in the muscle of fish species, namely, Mugil cephalus and Trachurus mediterraneus, respectively, caught from Iskenderun Bay, Turkey. Similarly Yap et al. [24] got $58.4 \mu \mathrm{g} / \mathrm{g}$ wet weight of $\mathrm{Zn}$ in the muscles of Tilapia fish (Oreochromis mossambicus) caught from a pond in Kelana Jaya. In a report, Ruelas-Inzunza and Páez-Osuna [27] recorded $388 \mu \mathrm{g} / \mathrm{g}$ of $\mathrm{Zn}$ in muscle of gray whale (Eschrichtius robustus), which is reasonably less than the values we recorded for fishes of River Kabul.

In the present study, Wallago attu accumulated $\mathrm{Zn}$ with mean value of $509.7 \pm 95.8$, seenghala was $2279.7 \pm 1614.9$, carpio was $3319.0 \pm 376.8$, and dyocheilus was $1175.7 \pm 649.0$ and bimaculatus had the mean value of $860.0 \pm 160.8 \mu \mathrm{g} / \mathrm{g}$ wet weight. $\mathrm{Zn}$ concentration in liver was, however, in the order of carpio $>$ seenghala $>$ dyocheilus $>$ bimaculatus $>$ attu.
This shows that the metal bioaccumulation was the highest in the liver of Cyprinus carpio and lowest in Wallago attu. Previously, Subathra and Karuppasamy [26] have reported $388 \mu \mathrm{g}^{-1}$ of $\mathrm{Zn}$ in liver of Eschrichtius robustus. The highest $\mathrm{Zn}$ concentration was found in the liver of Clarias gariepinus in treated sewage water [8]. Annune and Lyaniwura [29] reported that the liver of niloticus and gariepinus accumulated $\mathrm{Zn}$ more than other tissues. Similarly, van den Heever and Frey [8] had reported $\mathrm{Zn} 1060.57 \pm 14.61$ and $1935.5 \pm$ $70.89 \mu \mathrm{g} / \mathrm{g}$ wet weight of $\mathrm{Zn}$ in muscle and liver of fish putitora caught from the Kabul River. The results reveal that River Kabul is more polluted with $\mathrm{Zn}$ as compared to all the other water bodies, mentioned here.

Cadmium an anthropogenic metal pollutant is extremely toxic to aquatic animals with a long biological half-life and can produce both hepatic and renal injuries in mammals and fish [30]. Its access causes coronary artery disease, hypertension, emphysema, and chronic pulmonary diseases. Cadmium remains and accumulates in the respective uptake tissue during waterborne or dietary exposure but has also been shown to enter the circulation and accumulate to a significant extent in the liver [31]. The accumulation of $\mathrm{Cd}$ in the muscles and livers is given in Tables 1 and 2, respectively. Its mean values in muscles of $W$. attu, A. seenghala, $C$. carpio, L. dyocheilus, and O. bimaculatus were 68.0, 60.7, $53.3,66.7$, and $71.7 \mu \mathrm{g} / \mathrm{g}$, respectively. However, in muscles its bioaccumulation was in the order of $O$. bimaculatus $>W$. attu $>$ L. dyocheilus $>$ A. seenghala $>C$. carpio. Its accumulation was highest in the muscle of $O$. bimaculatus and lowest in $C$. carpio. In the livers, mean values of Cd were 64.3, 64.7, 58, 72.3 , and $138.3 \mu \mathrm{g} / \mathrm{g}$ wet weight, in the order of bimaculatus $>$ dyocheilus $>$ seenghala $>$ Wallago attu $>$ Cyprinus carpio. This shows that the metal bioaccumulation was highest in the liver of bimaculatus and lowest in carpio. In previous studies, Türkmen et al. [18] obtained $0.01-4.16\left(\mu \mathrm{g} / \mathrm{kg}^{-1}\right)$ of Cd in three commercially valuable fish species, namely, Saurida undosquamis, S. aurata, and Mullus barbatus of Turkey. In another study, Yap et al. [24] recorded $2.42 \mu \mathrm{g} / \mathrm{g}$ of Cd in muscles of Oreochromis mossambicu from a Kelana Jaya Pond. Made changes accordingly. Kumar et al. [20] have also reported 0.77 and $1.04 \mu \mathrm{g} / \mathrm{g}$ of Cd in certain fishes of Kayseri, Turkey. Bhattacharya et al. [15] recorded that muscle tissue accumulated more cadmium than gonads and skin of fishes. Our report shows a higher concentration of $\mathrm{Cd}$ in fishes of the Kabul River, as compared to the recommended international standards (Table 2). This study reports that River Kabul is more polluted with $\mathrm{Cd}$ as compared to that from different parts of the world.

Lead enters the aquatic environment through erosion and leaching from the lead dust fallout, combustion of gasoline, and municipal and industrial discharges. Lead is a leading cause of birth defects, cardiovascular disease, hypertension, neurological disease, kidney disease, learning disability, retardation, tooth cavities, and so forth [32]. Devi and Banerjee [33] reported reduction in serum protein contents of Aristichthys nobilis following exposure to lead. Lead Concentration in the muscle of attu was $599.3 \pm 188.3$, seenghala was $350.7 \pm 37.2$, carpio was $226.3 \pm 222.2$, dyocheilus was $528.7 \pm 236.4$, and bimaculatus was $407.0 \pm 126.6 \mu \mathrm{g} / \mathrm{g}$ wet 
weight. The concentration of $\mathrm{Pb}$ in muscle of different fish species was in the order of attu $>$ dyocheilus $>$ bimaculatus $>$ seenghala $>$ carpio, reflecting highest bioaccumulation in attu and lowest in carpio. While in livers attu had $623.3 \pm 276.5$, seenghala had $240.0 \pm 104.2$, carpio had $261.3 \pm 72.7$, dyocheilus had $377.0 \pm 300.2$, and bimaculatus had $1390.0 \pm 1530.2 \mu \mathrm{g} / \mathrm{g}$ wet weight of lead. Its concentration however varied in the order of bimaculatus $>$ attu $>$ dyocheilus $>$ carpio $>$ seenghala. This shows that the metal bioaccumulation is the highest in the liver of bimaculatus and lowest in seenghala. In earlier studies Ruelas-Inzunza and Páez-Osuna [27] have reported 0.9 and $4.2 \mu \mathrm{g} / \mathrm{g}$ of $\mathrm{Pb}$ in muscle of the gray whale and liver of sperm whale whereas Yilmaz [16] has recorded 7.45 and $1.3 \mu \mathrm{g} / \mathrm{g}$ wet weights of $\mathrm{Pb}$ in the muscle of Mugil cephalus and Trachurus mediterraneus, respectively. Yousafzai and Shakoori [9] had also reported $227.4 \pm 20.44$ and $136.8 \pm$ $9.08 \mu \mathrm{g} / \mathrm{g}$ wet weight of $\mathrm{Pb}$ in muscle and liver of Tor putitora caught from River Kabul.

\section{Conclusion}

Different countries have their standards of maximum permissible limits of different metals in the fish muscle with some variations depending upon the environmental conditions. Unfortunately in Pakistan such standards are not yet established or if prepared are not available to researchers. Therefore, the results relating to different metals in the fish muscle are compared with the U.S. Recommended Dietary Allowance (RDA) supplied by hundred grams ( $100 \mathrm{~g})$ serving fish muscle to prove the contention. Out of six heavy metals, $\mathrm{Zn}, \mathrm{Ni}, \mathrm{Cr}, \mathrm{Cd}$, and $\mathrm{Pb}$ are exceeding the RDA limits, while copper remains within the limits.

This shows that continuous fish consumption is not suitable for human health. However, as the fish is very rarely consumed by the people here due to many reasons, high health risk has not yet been identified and reported.

\section{Conflict of Interests}

The authors declare that there is no conflict of interests regarding the publication of this paper.

\section{Acknowledgments}

Financial support for publication of this paper was made by the Higher Education Commission of Pakistan funded Project no. 20-1409 entitled "Ethnogenetic Elaboration of KP through Dental Morphology and DNA Analysis." The authors admire the contrition of HEC Pakistan towards publication of the paper.

\section{References}

[1] R. K. Gresswell and A. Huxeley, Standard Encyclopedia of the World River and Lakes, Weidenfeld \& Nicolson, London, UK, 1965.

[2] J. A. Butt, "A liminological study of lotic water of NWFP Pakistan," Final Technical Report, Pakistan Agricultural Research Council, 1989.
[3] A. M. Yousafzai and A. R. Shakoori, "Heavy metal accumulation in the gills of an endangered south Asian freshwater fish as an indicator of aquatic pollution," Pakistan Journal of Zoology, vol. 40, no. 6, pp. 423-430, 2008.

[4] S. Kumar, S. A. Gaikwad, A. V. Shekdar, P. S. Kshirsagar, and R. N. Singh, "Estimation method for national methane emission from solid waste landfills," Atmospheric Environment, vol. 38, no. 21, pp. 3481-3487, 2004.

[5] A. Kouba, M. Buřič, and P. Kozák, "Bioaccumulation and effects of heavy metals in crayfish: a review," Water, Air, and Soil Pollution, vol. 211, no. 1-4, pp. 5-16, 2010.

[6] P. Trevor and F. Stephan, Pollution and Kabul River: An Analysis and Action Plan, IUCN/Environmental Planning and Development Department, Khyber Pakhtunkhwa, Pakistan, 1994.

[7] J. A. Butt and M. R. Mirza, "Fishes of the valley of Peshawar, NWFP, Biologia, vol. 27, 1981.

[8] D. J. van den Heever and B. J. Frey, "Human health aspects of the metals zinc and copper in tissue of the African sharptooth catfish, Clarias gariepinus, kept in treated sewage effluent and in the Krugersdrift Dam," Water SA, vol. 20, no. 3, pp. 205-212, 1994.

[9] A. M. Yousafzai and A. R. Shakoori, "Bioaccumulation of chromium, nickel, lead, copper and zinc in the Tur putitora as an indicator of presence of heavy metals loads in River Kabul Pakistan," Pakistan Journal of Zoology, vol. 8, pp. 341-347, 2006.

[10] Z.-Y. Huang, Q. Zhang, J. Chen, Z.-X. Zhuang, and X.-R. Wang, "Bioaccumulation of metals and induction of metallo-thioneins in selected tissues of common carp (Cyprinus carpio L.) coexposed to cadmium, mercury and lead," Applied Organometallic Chemistry, vol. 21, no. 2, pp. 101-107, 2007.

[11] M. D. Ptashynski and J. F. Klaverkamp, "Accumulation and distribution of dietary nickel in lake whitefish (Coregonus clupeaformis)," Aquatic Toxicology, vol. 58, no. 3-4, pp. 249-264, 2002.

[12] M. Kalay, Ö. Ay, and M. Canli, "Heavy metal concentrations in fish tissues from the Northeast Mediterranean Sea," Bulletin of Environmental Contamination and Toxicology, vol. 63, no. 5, pp. 673-681, 1999.

[13] K. O. Ipinmoroti, A. A. Oshodi, and R. A. Owolabi, "Comparative studies of metals in fish organs, sediment and water from Nigerian fresh water fish ponds," Pakistan Journal of Scientific and Industrial Research, vol. 40, no. 5-12, pp. 70-74, 1997.

[14] R. M. Galvin, "Occurrence of metals in water: an overview," Water SA, vol. 22, no. 1, pp. 7-18, 1996.

[15] A. K. Bhattacharya, S. N. Mandal, and S. K. Das, "Heavy metals accumulation in water, sediment and tissues of different edible fishes in upper stretch of Gangetic West Bengal," Trends in Applied Sciences Research, vol. 3, no. 1, pp. 61-68, 2008.

[16] A. B. Yilmaz, "Levels of heavy metals (Fe, Cu, Ni, Cr, Pb, and Zn) in tissue of Mugil cephalus and Trachurus mediterraneus from Iskenderun Bay, Turkey," Environmental Research, vol. 92, no. 3, pp. 277-281, 2003.

[17] F. E. Olaifa, A. K. Olaifa, A. A. Adelaja, and A. G. Owolabi, "Heavy metal contamination of Clarias gariepinus from a Lake and fish farm in Ibadan, Nigeria," African Journal of Biomedical Research, vol. 7, no. 3, pp. 145-148, 2004.

[18] A. Türkmen, M. Türkmen, Y. Tepe, and I. Akyurt, "Heavy metals in three commercially valuable fish species from İskenderun Bay, Northern East Mediterranean Sea, Turkey," Food Chemistry, vol. 91, no. 1, pp. 167-172, 2005. 
[19] D. Demirezen and K. Uruç, "Comparative study of trace elements in certain fish, meat and meat products," Meat Science, vol. 74, no. 2, pp. 255-260, 2006.

[20] B. Kumar, K. S. Sajwan, and D. P. Mukherjee, "Distribution of heavy metals in valuable coastal fishes from North East Coast of India," Turkish Journal of Fisheries and Aquatic Sciences, vol. 12, no. 1, pp. 81-88, 2012.

[21] P. R. Palaniappan, S. Karthikeyan, and S. Sabhanayakam, "Studies on the effects of heavy metal nickel on gills of fingerlings of an edible fish Cirrhinus mrigala," Pollution Research, vol. 22, no. 2, pp. 247-250, 2003.

[22] US Environmental Protection Agency, "Hazardous air pollutant hazard summary," in Risk Information System, Fact Sheets, EPA, 1998.

[23] D. F. Woodward, A. M. Farag, H. L. Bergman et al., "Metalscontaminated benthic invertebrates in the Clark Fork River, Montana: effects on age- 0 brown trout and rainbow trout," Canadian Journal of Fisheries and Aquatic Sciences, vol. 52, no. 9, pp. 1994-2004, 1995.

[24] C. K. Yap, A. Ismail, and P. K. Chu, "Concentration of Cd, Cu and $\mathrm{Zn}$ in the fish Tilapia, Oreochromis mossambicus caught from a Kelena Jaya pond," Asian Journal of Water, Environment and Pollution, vol. 2, pp. 65-70, 2005.

[25] V. F. Marijić and B. Raspor, "Metallothionein in intestine of red mullet, Mullus barbatus as a biomarker of copper exposure in the coastal marine areas," Marine Pollution Bulletin, vol. 54, no. 7, pp. 935-940, 2007.

[26] S. Subathra and R. Karuppasamy, "Bioassay evaluation of acute toxicity levels of cadmium on mortality and behavioural responses of an air-breathing fish Bloch Channa punctatus," Journal of Experimental Zoology, vol. 6, pp. 245-250, 2003.

[27] J. Ruelas-Inzunza and F. Páez-Osuna, "Distribution of Cd, $\mathrm{Cu}, \mathrm{Fe}, \mathrm{Mn}, \mathrm{Pb}$ and $\mathrm{Zn}$ in selected tissues of juvenile whales stranded in the SE Gulf of California (Mexico)," Environment International, vol. 28, no. 4, pp. 325-329, 2002.

[28] S. J. Clearwater, S. J. Baskin, C. M. Wood, and D. G. McDonald, "Gastrointestinal uptake and distribution of copper in rainbow trout," Journal of Experimental Biology, vol. 203, no. 16, pp. 2455-2466, 2000.

[29] P. A. Annune and T. T. Iyaniwura, "Accumulation of two trace metals in tissues of freshwater fishes, Oreochoromis niloticus and Clarias gariepinus," Journal of Aquatic Food Product Technology, vol. 2, no. 3, pp. 5-18, 1994.

[30] K. Mai, H. Li, Q. Ai et al., "Effects of dietary squid viscera meal on growth and cadmium accumulation in tissues of Japanese seabass, Lateolabrax japonicus (Cuvier 1828)," Aquaculture Research, vol. 37, no. 11, pp. 1063-1069, 2006.

[31] J. C. McGeer, C. Szebedinszky, D. G. McDonald, and C. M. Wood, "Effects of chronic sublethal exposure to waterborne $\mathrm{Cu}$, $\mathrm{Cd}$ or $\mathrm{Zn}$ in rainbow trout 2: tissue specific metal accumulation," Aquatic Toxicology, vol. 50, no. 3, pp. 245-256, 2000.

[32] R. P. Mason, W. F. Fitzgerald, and F. M. M. Morel, “The biogeochemical cycling of elemental mercury: anthropogenic influences," Geochimica et Cosmochimica Acta, vol. 58, no. 15, pp. 3191-3198, 1994.

[33] R. Devi and K. Banerjee, "Toxicopathological impact of sublethal concentration of lead nitrate on the aerial respiratory organs of murrel, Channa striata," Iranian Journal of Environmental Health Science \& Engineerin, vol. 4, pp. 249-256, 2007. 

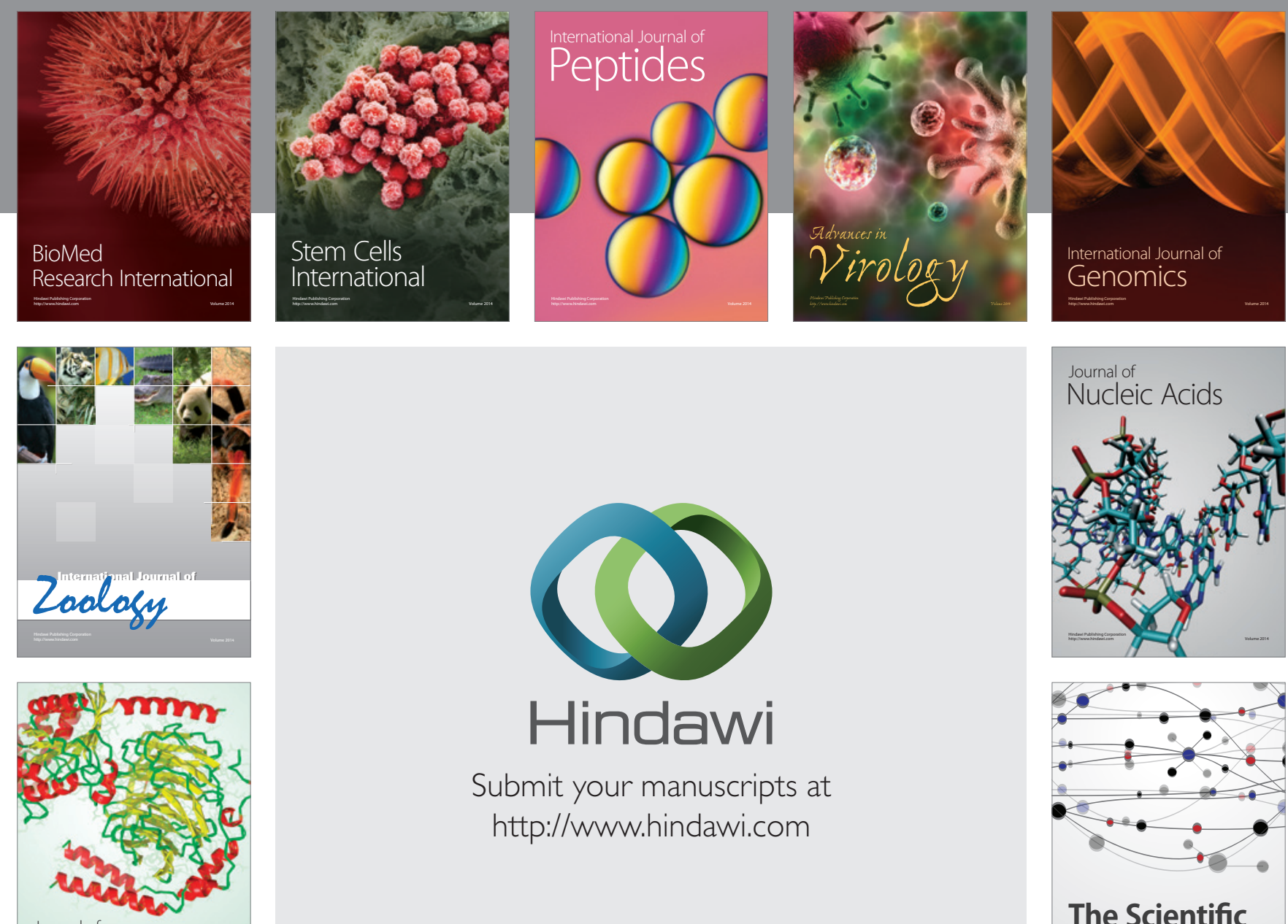

Submit your manuscripts at

http://www.hindawi.com

Journal of
Signal Transduction
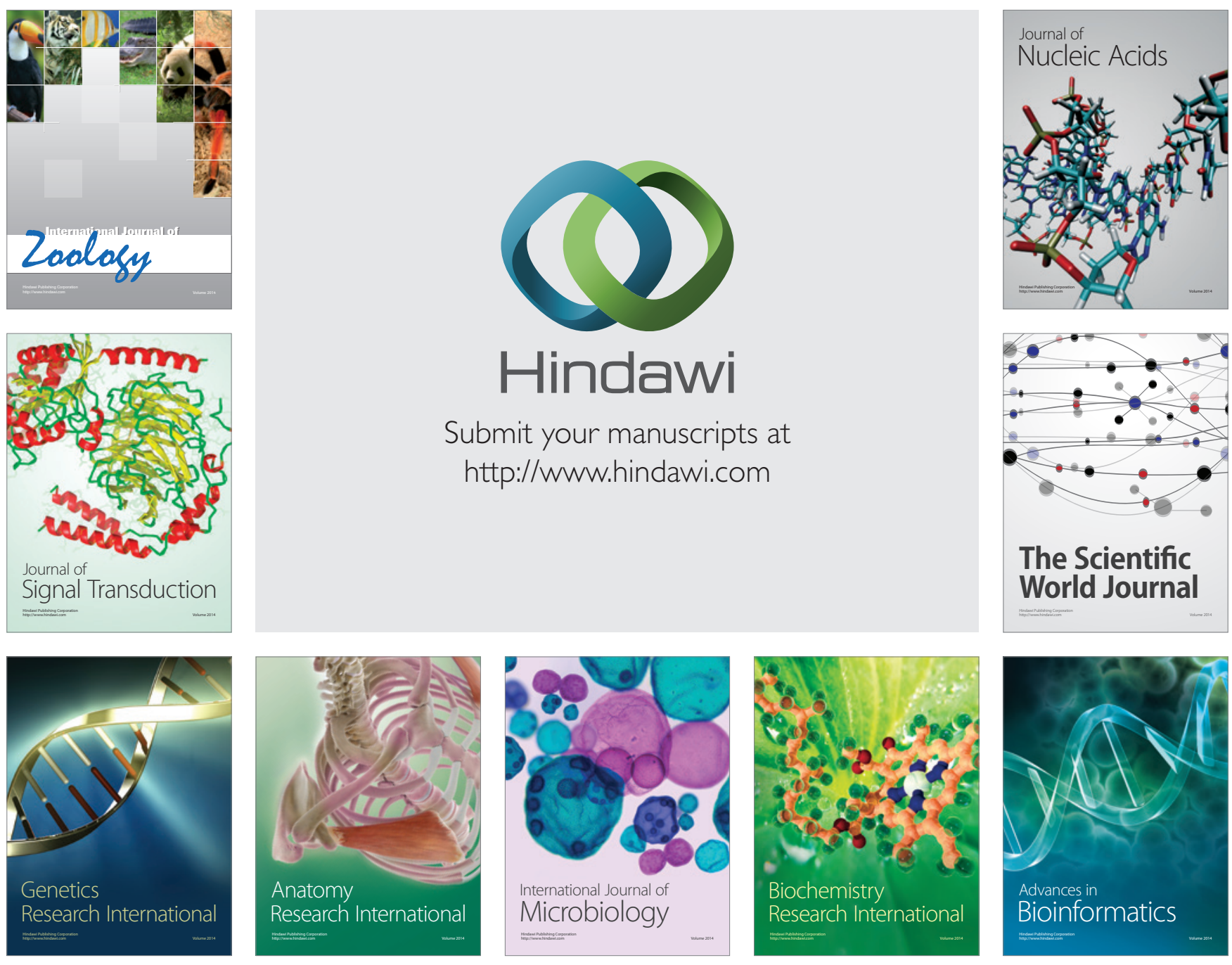

The Scientific World Journal
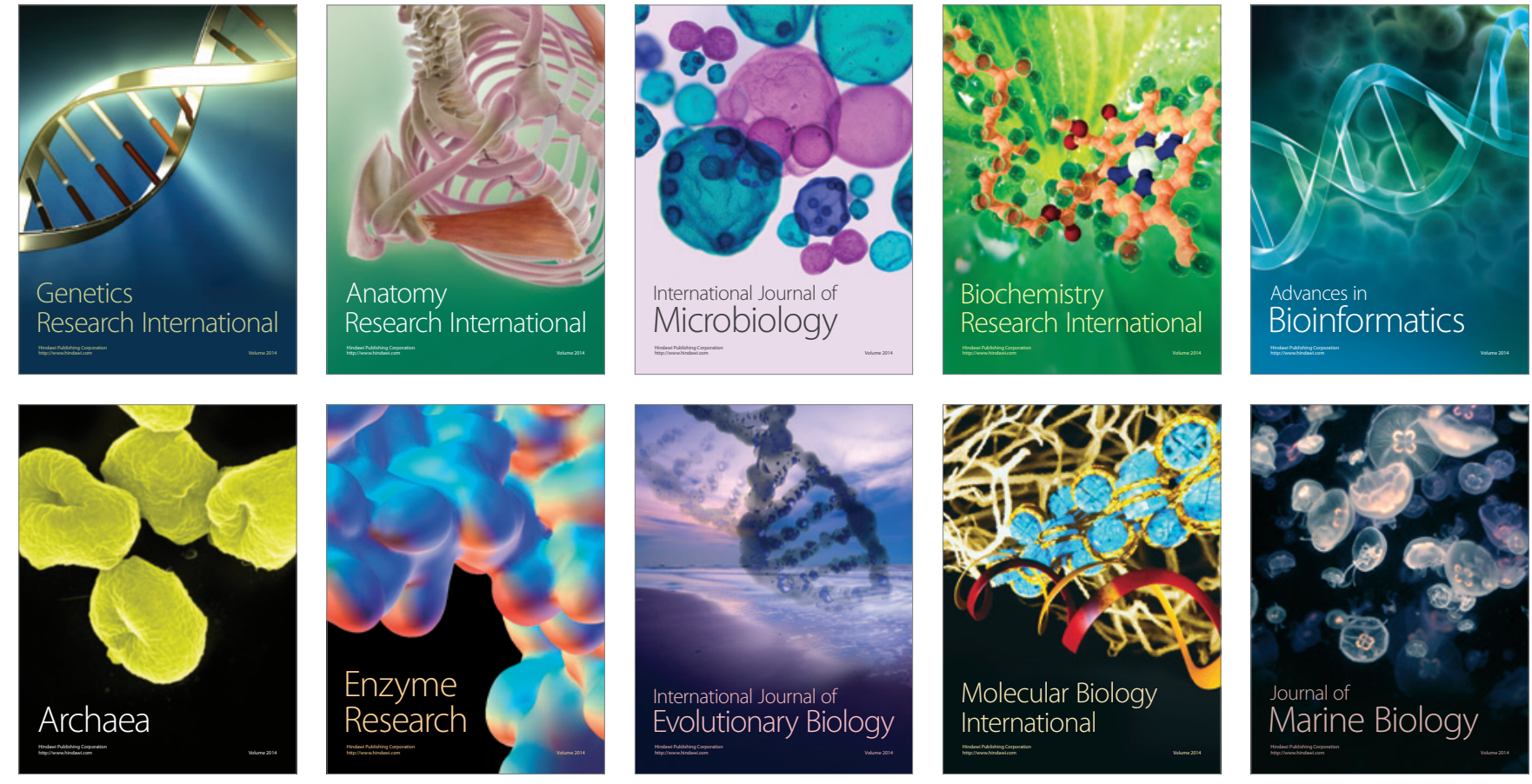